\title{
Applications of mechanically deboned meat in sausage mass
}

\author{
L. RIIHONEN,* K. HÄMÄLÄINEN** and E. VÄÄNÄNEN** \\ * Finnish Meat Research Centre, Box 56, \\ SF-13101 Hämeenlinna, Finland \\ ** Osuusteurastamo Karjaportti, Box 60, \\ SF-50101 Mikkeli, Finland
}

\begin{abstract}
The use of mechanically deboned meat (MDM) and its proportion in homogeneous sausage mass was investigated. A test Bologna containing $7.50 \%$ mechanically deboned meat was used. Two deboning machines, an Inject Star based on pressure and an auger-type Poss machine based on scraping, were used. The water contents of the masses varied between 28.36 and $43.36 \%$.

Test sausages containing the same amounts of meat recovered by the Inject Star and Poss deboners were surprisingly similar in colour. Calcium contents of samples were $0.11 \%-0.18 \%$, and the corresponding ash contents $2.6-2.9 \%$. The $\mathrm{pH}$ values of all the test sausages were similar, about 6.4. Fat contents in samples made using MDM recovered with the Inject Star deboner were lower than those in the samples made using MDM recovered with the Poss deboner. On the basis of chemical quality indices the shelf lives of all the test sausages were similar.
\end{abstract}

Index words: mechanically deboned meat (MDM), use of MDM, sausage, shelf-life of sausage

\section{Introduction}

Mechanical deboning is an inexpensive and convenient method of recovering meat attached to bones. Many processed meats are finely minced, so mechanically deboned meat (MDM) can be used to economic advantage. In the case of poultry products there is no limit to the amount of mechanically processed poultry meat that can be added for example in the USA, but for red meats the maximum quan- tity of mechanically separated beef, pork, or lamb meat is limited to 20 percent of the meat fraction (1).

FIELD (2) reported that flavour not associated with rancidity, texture, or juiciness in products containing MDM may vary depending on the amount of red bone marrow in the MDM and on the amount of MDM in the finished product. FIELD (3) also observed 
that sensory panels have not been able to detect differences in juiciness or flavour when $10 \%$ mechanically deboned meat is added to formulations.

The bones from the vertebral column, ribs and sternum are most suitable for mechanical deboning because they usually have more lean meat attached and thus yield a greater percentage of mechanically separated tissue (4, $5)$. Round bones are least suitable for mechanical deboning since they have very little lean meat attached and the marrow is primarily fat. FiELD et al. (6) also reported that the protein content in mechanically deboned meat was lower and the fat content higher than in similar hand deboned meat.

Gillet et al. (7) have shown that mechanical recovering removed approximately half of the connective tissue from beef and pork trimmings. The tendency for jelly pockets to form in salami was reduced by using such material, and the texture and tenderness were improved by the recovering operation.

Marshall et al. (8) studied the effects of adding MDM from pork to frankfurter sausages on cooking loss and texture. They manufactured frankfurters comprising $10 \%$, $25 \%$ and $40 \%$ MDM, calculated on total batch weight, and found that the cooking loss increased with increasing MDM concentration. However, when the sausages were judged for texture by sensory evaluation, the batch containing $10 \%$ MDM was ranked the best, followed by the control and the batch containing 25\% MDM. The batch containing 40\% MDM was rated 'very mushy'.

Microbial counts in frankfurters containing $15 \%$ mechanically deboned turkey meat after frozen $\left(-24^{\circ} \mathrm{C}\right)$ storage for 7 days were generally low (9). Joseph et al. (10) claimed that the microbial load in MDM can be as low as that of handboned trimmings if proper sanitation and temperature control are employed.

The aim of the present work was to study the use of mechanically recovered meat and its optimum proportion in homogeneous sausage meats.

\section{Material and methods}

Bologna sausage was chosen as the basic sausage, because it best reveals the benefits and disadvantages of the added mechanically recovered meat. The formulation of the basic sausage is presented in Table 1.

In preliminary trials, $2.5 \%, 5 \%, 7.5 \%$, $10 \%$ and $12.5 \%$ MDM was used in the test sausages and on the basis of these tests the optimum proportion of $7.5 \%$ mechanically recovered meat was used in subsequent experiments. High concentrations of MDM in the formulation resulted in a very soft, dark and inelastic sausage.

The research was carried out at the production plant Osuusteurastamo Karjaportti in Mikkeli and in Hämeenlinna at the Finnish Meat Research Centre, and partly at the plant of Lihapolar Oy in Kuopio. Inject Star, P-60 (Hollstein-Fuhrman, Vienna, Austria) and Poss, PDX (Poss Limited, Hamilton, Canada) machines were used to recover MDB (mechanically deboned beef) and MDP (mechanically deboned pork) to be used in the sausages. The added water content of the sausages was changed according to the test programme describes in the following.

\section{Sausage tests}

Test sausages in experiments I and II were

Table 1. The formulation of the test Bologna contained mechanically deboned meat.

\begin{tabular}{lrlr}
\hline Meat cuts & $\%$ & Ingredients & $\%$ \\
\hline N2 & 2.78 & Milk powder & 5.06 \\
MDB & 1.01 & Potato flour & 6.08 \\
R2 & 5.57 & Ascorbic acid & 0.06 \\
SE & 1.37 & Glucose & 0.10 \\
S0 & 3.54 & Spices & 0.15 \\
S2 & 30.38 & Phosphate & 0.15 \\
MDP & 1.01 & NaNO & $(10 \%)$ \\
S5-emulsion & 12.49 & NaCl & 0.12 \\
& & Water & 1.77 \\
\hline
\end{tabular}

$\mathrm{N}$ - and R-cuts were beefcuts, with fat contents of N2 $<20 \%$ and $\mathrm{R} 2<22 \%$. The connective tissue values of both cuts were $6 \%$. Fat contents of the pork cuts were: SE $3-5 \%$, S0 $10-12 \%$ and S5 $<30 \%$, and connective tissue values were $2 \%$ in SE, $3 \%$ in S0 and $27 \%$ in S5. 
Table 2. Experiments I and II with the test Bologna. The percentages of MDM and total water in the test sausage formulae. Mechanically deboned meat (MDM) was beef (MDB) in experiment I and pork (MDP) in experiment II recovered with the Inject Star deboner.

\begin{tabular}{lrrrrrr}
\hline Samples & \multicolumn{1}{c}{1} & \multicolumn{1}{c}{2} & \multicolumn{1}{c}{3} & \multicolumn{1}{c}{4} & \multicolumn{1}{c}{5} & \multicolumn{1}{c}{6} \\
\hline MDM & 2.02 & 7.50 & 7.50 & 7.50 & 7.50 & 7.50 \\
Water & 28.36 & 28.36 & 31.36 & 34.36 & 37.36 & 40.36 \\
\hline
\end{tabular}

made using mechanically deboned meat recovered with the Inject Star deboner as presented in Table 2. In all the test sausages milk powder, potato flour, additives and spices were added in the same proportion as in the basic formulation. Test sausages in experiments III and IV were made using mechanically deboned meat recovered with the Poss deboner. In experiment $\mathrm{V}$ all the samples were made from MDP and MDB recovered by Inject Star and Poss as described in the following (see also Table 3). In all tests MDB and MDP were from mixed beef and pork bones and the MDM was separated in a freshly disinfected deboning machine. In experiments I-IV the sausages were in natural casings, whereas the sausages in Test V were prepared with cellulose casings. All experimental sausages were stuffed by hand. The technical quality of sausages was best in experiment $\mathrm{V}$.

\section{Evaluation of meat and sausage quality}

\section{Water holding capacity}

The method developed by Pohja (11) was used for determining the water holding capacity of the meat.

\section{Consistency}

Consistency was measured in an Instron testing apparatus (Model 4301), using a weight head with a diamter of $5.5 \mathrm{~cm}$. A $6 \mathrm{~cm}$ slice was cut from the test sausage, the side of the slice was depressed to a depth of $0.5 \mathrm{~cm}$. The compression force $(\mathrm{kp})$ was measured as the maximum height of force-deformation curve.

\section{Sensory evaluation}

A trained 6-member panel evaluated the appearance (range $0-3 ; 0=$ unacceptable... $2=$ acceptable and $3=$ flawless), texture (range $0-5 ; 0=$ unacceptable. . .3 $=$ acceptable, $4=$ flawless and $5=$ exellent), taste and smell (range $0-7 ; 0=$ unacceptable . .2 $-3=$ poor, $4=$ acceptable, $5=$ flawless, $6=$ good and $7=$ exellent) of the test sausages.

Other analyses used for the evaluation of meat and sausage quality have been presented earlier RIIHONEN et al. (12).

\section{Results and Discussion}

Tables 4 and 5 show the analytical results of the meat recovered using the two different machines. Meat recovered in the Poss machine was organoleptically noticeably smoother, and lighter in colour, than that recovered in the Inject Star. The greatest differences between meat recovered using the Poss and Inject Star machines were in calcium and ash contents.

The water holding capacity was surprisingly low $(\mathrm{P}<0.05)$ in sample BP (Table 4). Other workers have reported that frozen, mechanically recovered meat has less water

Table 3. Experiment $\mathrm{V}$ with the test Bologna. The percentages of mechanically deboned beef (MDB) and pork (MDP) and total water in the test sausage formulae.

\begin{tabular}{lcccccrrr}
\hline Samples & 1 & 2 & 3 & 4 & 5 & 6 & 7 & 8 \\
\hline MDB & $1.01 \mathrm{BP}$ & $3.75 \mathrm{BP}$ & $3.75 \mathrm{BP}$ & $3.75 \mathrm{BP}$ & $1.01 \mathrm{BI}$ & $3.75 \mathrm{BI}$ & $3.75 \mathrm{BI}$ & $3.75 \mathrm{BI}$ \\
MDP & $1.01 \mathrm{PP}$ & $3.75 \mathrm{PP}$ & $3.75 \mathrm{PP}$ & $3.75 \mathrm{PP}$ & $1.01 \mathrm{PI}$ & $3.75 \mathrm{PI}$ & $3.75 \mathrm{PI}$ & $3.75 \mathrm{PI}$ \\
Water & 28.36 & 28.36 & 31.36 & 34.36 & 28.36 & 28.36 & 31.36 & 34.36 \\
\hline
\end{tabular}

BI and BP were mechanically deboned beef recovered using the Inject Star (I) and Poss (P) machines.

PI and PP were mechanically deboned pork recovered using the Inject Star (I) and Poss (P) machines. 
Table 4. Analyses of mechanically deboned meat used in the test sausage. MDB and MDP recovered using the Inject Star are designated BI and PI. MDB and MDP recovered using the Poss deboner are designated BP and PP.

\begin{tabular}{|c|c|c|c|c|c|c|}
\hline Sample & Water $\%$ & Fat $\%$ & Ash \% & WHC $* \%$ & $\mathrm{pH}$ & Colour $\%$ \\
\hline BI & $63.4^{\mathrm{a}}$ & 20.7 & $1.4^{\mathrm{a}}$ & 45 & $6.3^{a}$ & 19.0 \\
\hline BP & $56.0^{\mathrm{b}}$ & 25.1 & 2.9 & 20 & $6.6^{b}$ & 28.0 \\
\hline PI & $62.9^{\mathrm{a}}$ & 19.5 & $1.1^{\mathrm{a}}$ & 30 & $6.3^{\mathrm{a}}$ & 26.2 \\
\hline PP & $55.8^{\mathrm{b}}$ & 30.1 & 3.5 & 39 & $6.6^{b}$ & 30.5 \\
\hline
\end{tabular}

ab Means in the same column bearing the same letters are not significantly different $(\mathrm{P}>0.05),{ }^{*} \mathrm{WHC} \%$ is waterholding-capacity.

Table 5. Analysis of the test Bologna containing MDM recovered using the Inject Star and Poss deboners.

\begin{tabular}{|c|c|c|c|c|c|c|}
\hline \multirow[b]{4}{*}{ Samples } & \multicolumn{6}{|c|}{ Test Sausages } \\
\hline & \multicolumn{3}{|c|}{ MDM by Poss } & \multicolumn{3}{|c|}{ MDM by Inject Star } \\
\hline & \multirow{2}{*}{$\frac{2.02 \%}{1}$} & \multicolumn{2}{|c|}{$7.50 \%$} & \multirow{2}{*}{$\frac{2.02 \%}{5}$} & \multicolumn{2}{|c|}{$7.50 \%$} \\
\hline & & 2 & 3 & & 6 & 7 \\
\hline Water \% & $64.7^{\mathrm{a}}$ & $62.2^{\mathrm{b}}$ & $63.3^{b}$ & $66.1^{\mathrm{c}}$ & $65.9^{c}$ & $66.6^{c}$ \\
\hline Protein \% & $10.9^{\mathrm{ab}}$ & $10.7^{\mathrm{a}}$ & $10.5^{\mathrm{a}}$ & $11.1^{b}$ & $11.3^{b}$ & $11.1^{\mathrm{b}}$ \\
\hline Fat $\%$ & $18.0^{a}$ & $17.8^{a}$ & $17.7^{\mathrm{a}}$ & $14.8^{b}$ & $14.4^{b}$ & $14.4^{b}$ \\
\hline Ash $\%$ & $2.9^{\mathrm{a}}$ & $2.9^{\mathrm{a}}$ & $2.8^{\mathrm{a}}$ & $2.7^{\mathrm{b}}$ & $2.6^{\mathrm{b}}$ & $2.6^{\mathrm{b}}$ \\
\hline Calcium $\%$ & $0.10^{\mathrm{a}}$ & $0.18^{b}$ & $0.18^{b}$ & $0.10^{\mathrm{a}}$ & $0.10^{\mathrm{a}}$ & $0.10^{a}$ \\
\hline Consistency kp & $1.2^{\mathrm{a}}$ & $1.5^{\mathrm{bc}}$ & $1.4^{\mathrm{c}}$ & $1.6^{\mathrm{b}}$ & $1.6^{\mathrm{b}}$ & $1.4^{\mathrm{c}}$ \\
\hline Colour \% & $62.7^{a}$ & $56.3^{\mathrm{b}}$ & $57.0^{b}$ & $62.7^{\mathrm{a}}$ & $57.3^{b}$ & $57.7^{\mathrm{c}}$ \\
\hline
\end{tabular}

abc Means in the same row bearing the different letter are significantly different $(\mathrm{P}<0.05)$.

holding capacity than unfrozen meat $(7,8)$. Water holding capacity is influenced not only by the freezing rate but also by the $\mathrm{pH}$ of the meat, which is higher in mechanically recovered meat than in hand boned meat. More water exudes from the meat during slow freezing, thus lowering its water holding capacity. The water holding capacity of meat is also influenced by the the freezing time and temperature, the rate of thawing and the fat and collagen contents. PuolanNe and TurkKI (13) studied the effects of frozen storage on the water holding capacity of the raw materials of cooked sausage and concluded that frozen storage of ground meat results in a strong decrease in water holding capacity. In the case of pork the minimum level is reached after $6-9$ months, but with beef the decrease is linear for at least 12 months.

In this work the colour retention qualities of meats recovered by the two machines were also compared. Colour changes were rather similar, with the darkest mechanically deboned beef recovered in the Inject Star changing the least $(\mathrm{P}<0.05)$.

When examining the keeping qualities of meat during storage at $+4^{\circ} \mathrm{C}$ using the free fatty acid (FFA\%) and peroxide value, it was noticed that the FFA \% -value changed more in the mechanically deboned beef and pork recovered in the Inject Star deboner than in the corresponding samples recovered in the Poss machine (Figure 1).

\section{Sausage analyses}

Colour

Before cooking, a colour difference was noticed between samples $1-4$ and samples $5-6$. This difference disappeared during cooking. It was, however, observed that test sausages containing the same amount of meat and recovered in the Inject Star or Poss machines were surprisingly similar in colour (Figure 2). The 


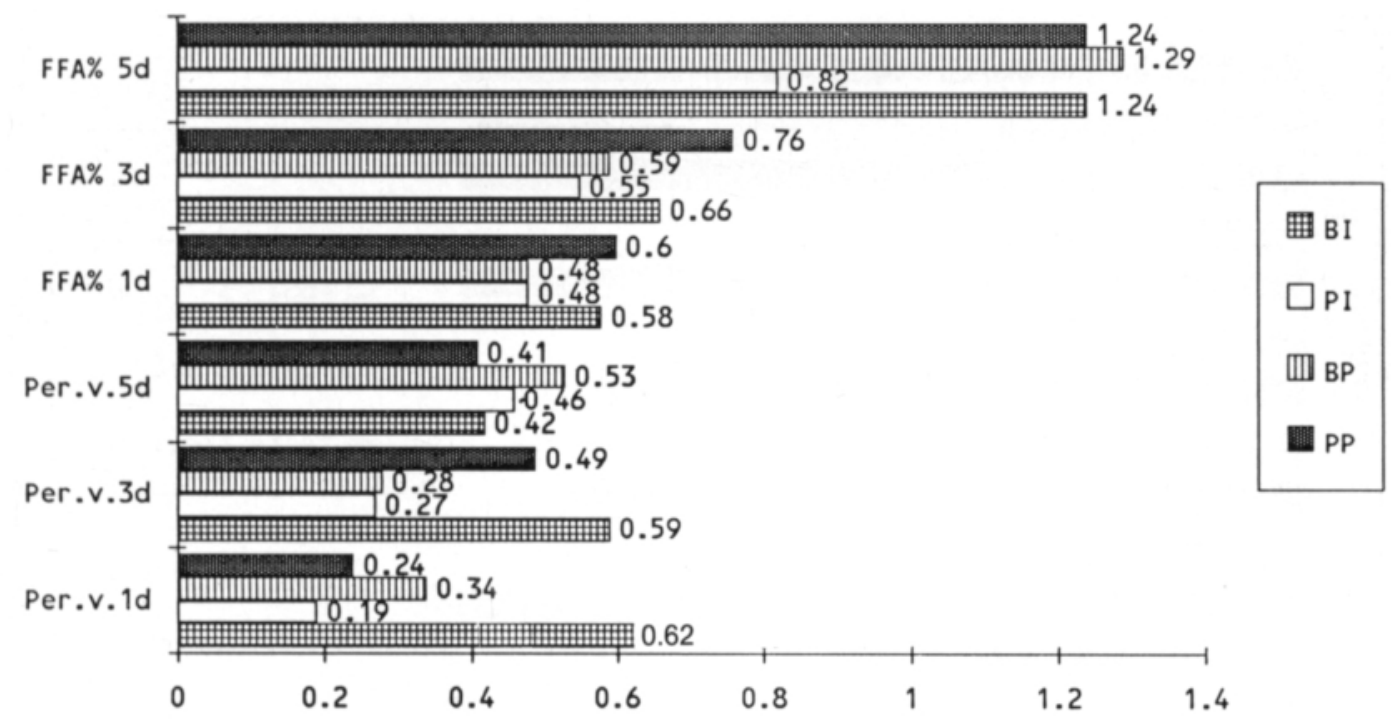

Fig. 1. Peroxide value (millieqvivalents of oxygen $/ \mathrm{kg}$, meq $\mathrm{O} / \mathrm{kg}$ ) and free fatty acid (FFA \%) during storage at $+4^{\circ} \mathrm{C}$. The test cuts BI (MDB) and PI (MDP) were recovered using the Inject Star deboner, BP (MDB) and PP (MDP) using the Poss deboner. Mean values of three replicates analysed in duplicate. Standard deviations $\leq 0.4$.

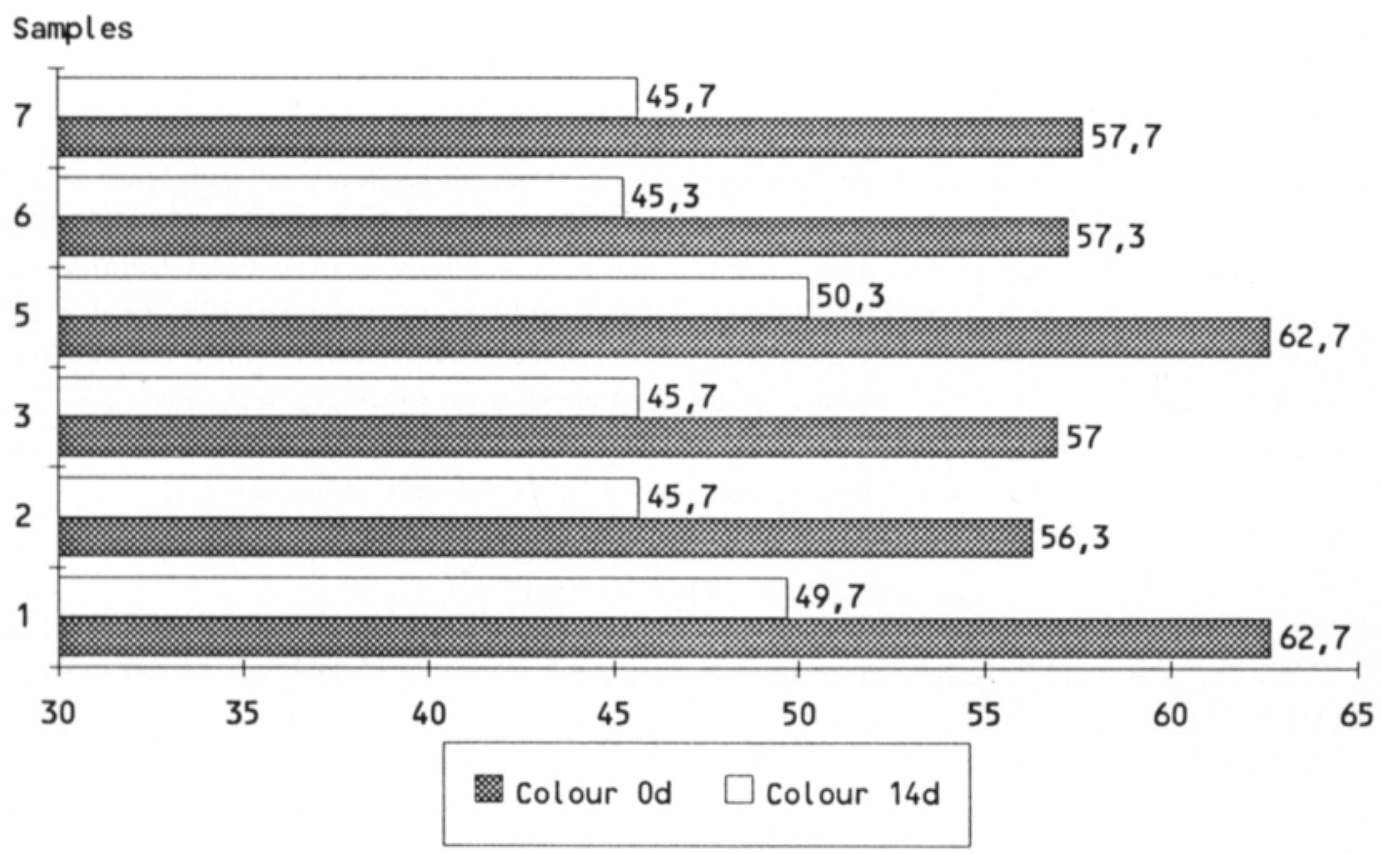

Fig. 2. Colour $(\%)$ in the test sausages (samples $1,2,3,5,6,7)$ during 1 day and after 14 days' storage at $+4^{\circ} \mathrm{C}$. Mean values of three replicates analysed in duplicate. Stardard deviations $\leq 1.5$.

colour change of stored sausages was caused by surface dehydration and oxidation of the meat pigments. It has been reported that more than $90 \%$ of frankfurter-type sausages have a reddish colour, the rest being greyish-white (14) 


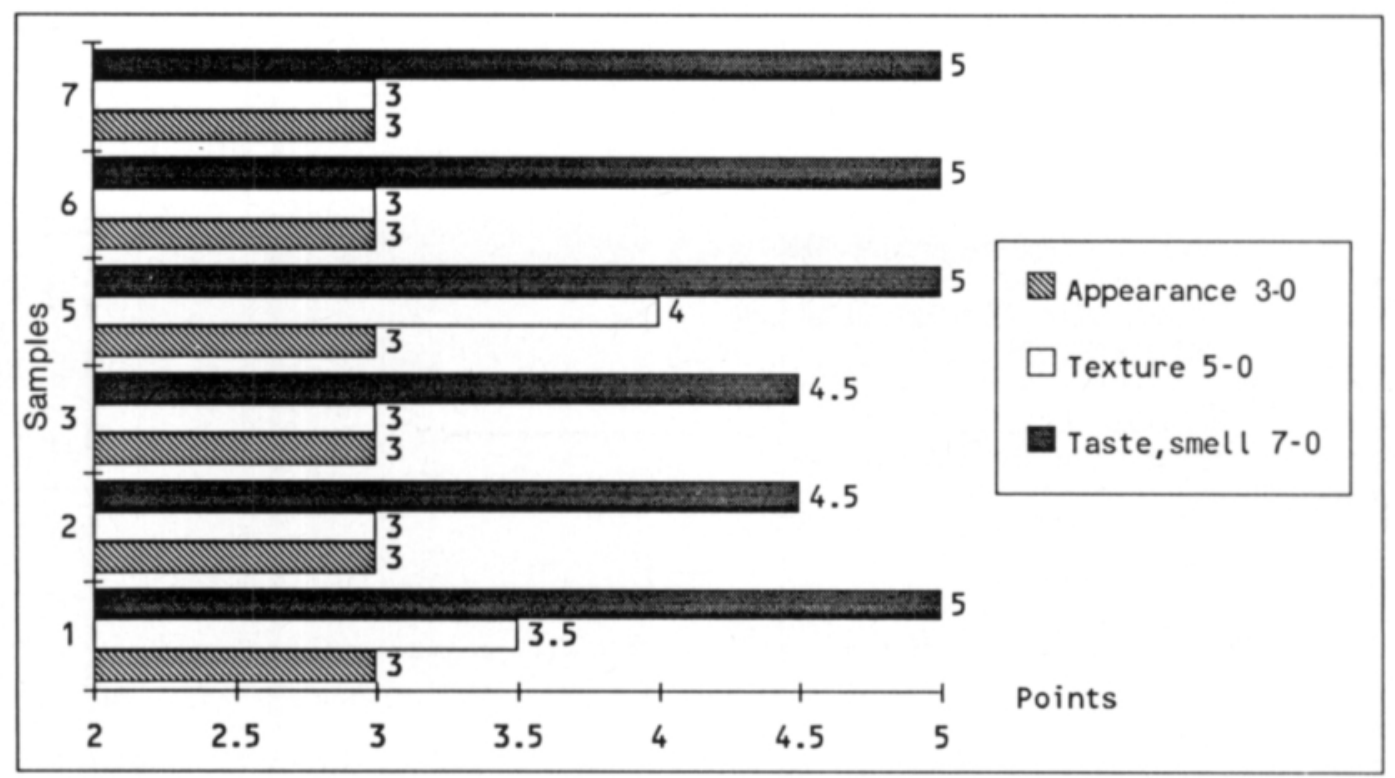

Fig. 3. Sensory evaluation of the test sausages (samples 1, 2, 3, 5, 6, 7); appearance (range $0-3 ; 0=$ useless... $2=$ acceptable and $3=$ flawless), texture (range $0-5 ; 0=$ useless... $3=$ acceptable, $4=$ flawless and $5=$ exellent), taste and smell (range $0-7 ; 0=$ useless...2 $-3=$ poor, $4=$ acceptable, $5=$ flawless, $6=$ good and $7=$ exquisite)

\section{Sensory quality}

Figure 3 illustrates the results of sensory analysis. Sample 5 was judged somewhat better than the others in taste, smell, appearance and texture. FIELD (15) concluded that acceptability is for the most part based on sensory evaluation, i.e. colour, texture and flavour, although the suspicious attitude of consumers towards new products often plays an important, if subconscious part.

\section{Consistency}

Consistency proved to be best in samples 5 and 6 (Table 5). These results are in agreement with those of Field (15) and SMith (16), who reported improved textural quality when mechanically deboned meat was added to ground beef and mutton in the range $5-25 \%$.

Similarly, a more pleasing texture, which gives fresh sausage an extra bite, is often obtained when $5-10 \%$ mechanically deboned meat is added, but a grainy or gritty texture may result in products with more than $30 \%$ mechanically deboned meat.

\section{Calcium content}

The calcium contents of samples 2 and 3 were about $0.18 \%$, significantly different $(\mathrm{P}<0.05)$ from those of samples 1 and $5-7$, which were approximates $0.10 \%$ (Table 5). This result was logical, because the calcium content of meat recovered in the Poss machine was generally higher than that of meat recovered in the Inject Star (Table 4).

\section{$\mathrm{pH}$ and fat}

All test sausages had similar $\mathrm{pH}$ values of between 5.8 and 6.0. The fat content in samples $5-7$ was lower than in samples $1-3$, because the fat contents of BP and PP were lower than those of BI and PI (Tables 4 and 5).

\section{Storage properties}

\section{Microbiological keeping qualities}

The microbiological keeping qualities of samples 1 and 3 were the best. When comparing the effects of meats recovered by the two machine types on the microbiological 


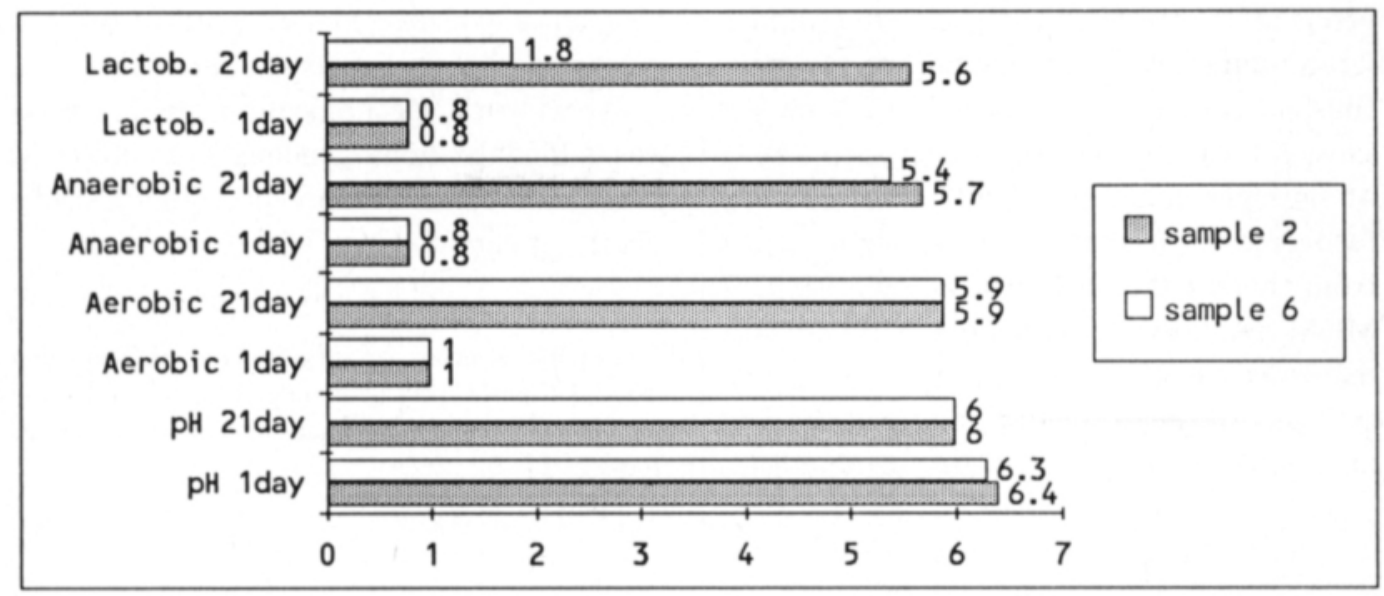

Fig. 4. Microbial counts $(\log (\mathrm{cfu} / \mathrm{g}))$ and $\mathrm{pH}$-values in the test sausages during storage at $+4^{\circ} \mathrm{C}$. The test sample 2 contained $3.75 \%$ MDB and 3.75\% MDP recovered using the Inject Star deboner and sample 6 correspondingly using the Poss deboner. Mean values of three replicates analysed in duplicate. Standard deviations $\leq 0.3$.

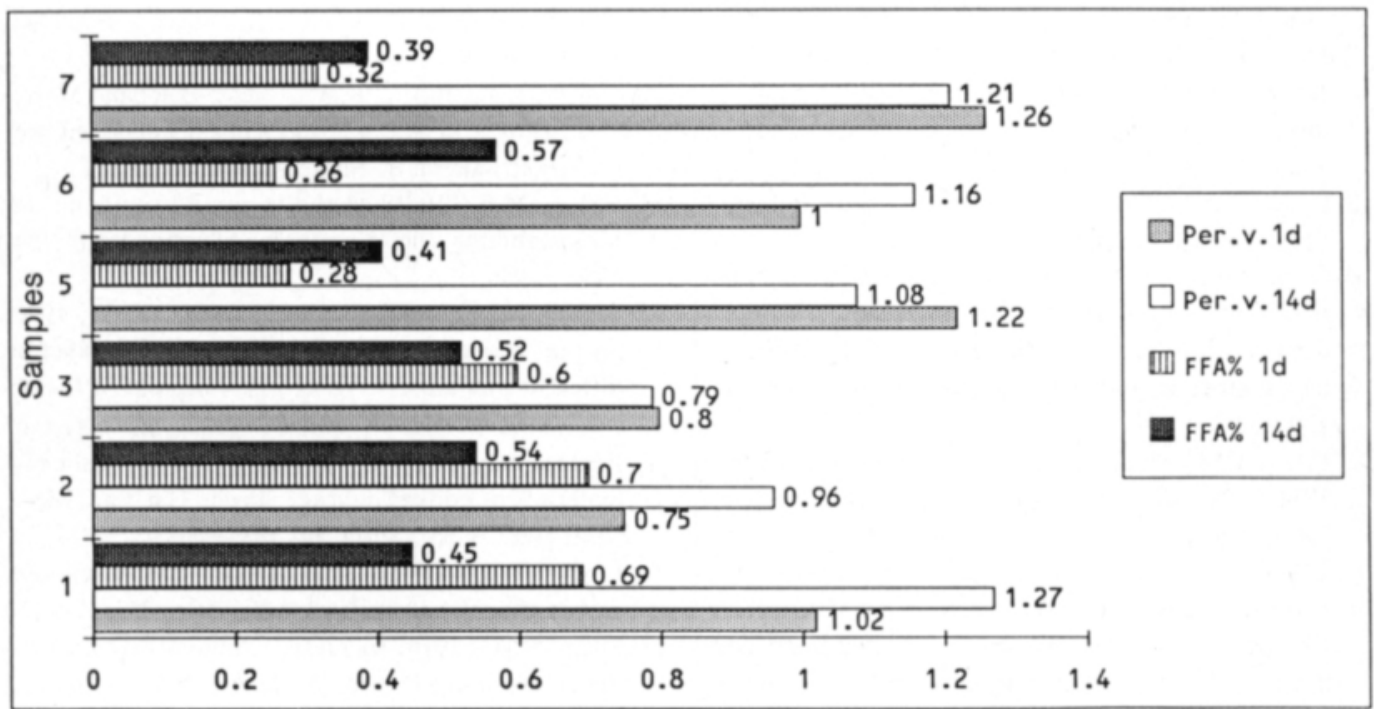

Fig. 5. Peroxide value (millieqvivalents of oxygen $/ \mathrm{kg}$, meq O/kg) and free fatty acid (FFA \%) in the test sausages (samples $1,2,3,5,6,7$ ) during storage at $+4^{\circ} \mathrm{C}$. Mean values of three replicates analysed in duplicate. Standard deviations $\leq 0.5$.

keeping qualities of sausages, no great differences were found. However sample 6, after 21 days of storage, had a lower lactic acid bacterial count than the other samples (Figure 4).

\section{Chemical storage properties}

Chemical storage properties were measured using the peroxide and free fatty acid values.
The results presented in Figure 5 indicate that the initially higher peroxide values in samples 5-7 did not increase proportionately during the two-week storage period in comparison with samples $1-3$.

No significant differences were observed in the effects of the meats recovered by these two (pressure-based and auger) machine types. The differences between the non-homoge- 
neous meat recovered using the Poss and Inject Star machines could not be detected in the finished sausages. The shelf life of the test sausages was two to three weeks. Storability of sausages containing $7.50 \%$ mechanically recovered meat did not differ significantly from that of the basic test bologna $(2.02 \%$ MDM) made at the same time. Mechanically recovered meat accelerated the development rancidity of the sausage slightly, but this was not detected in the sensory evaluations.

\section{References}

1 Kastner, C.L. and Kropf, D.H., 1986. Processed meat products and safety issues. Dairy and Food Sanitation, 6, 186-193

2 Field, R.A. and Arasu, P., 1981. A simple method for estimating amount of red marrow present in mechanically deboned meat. J. Food Sci. 46: 16221623

3 Field, R.A., 1976. Mechanically deboned red meat. Food Technol. 30(9): 38-48

4 Ockerman, H.W., Houben, J.H. and Krol, B., 1981. Effect of bone source and storage on the role of mechanically deboned pork in rancidity development in a cooked and smoked sausage. J. Food Sci. 46: 220-226

5 Field, R.A., Riley, M.L. and Corbridge, M.H., 1974. Influence of yield on calsium content of mechanically deboned lamp and mutton. J. Food Sci. 39: 285-287

6 Field, R.A., Kruggel, W.G. and Riley, M.L., 1976. Characteristics of MDM hand separated meat and bone residue from bones destined for rendering. $\mathbf{J}$. Anim. Sci. 43: 755-758

7 Gillett, T.A, Kamchorn Tantikarnjathep and An. DREWS, S.J., 1976. Mechanically desinewed meat: its yield, composition and effect on palatability of cooked salami. J. Food Sci. 41: 766-769

8 Marshall, W.H., Smith, G.C., Dutson, T.R. and CARPEnTER, Z. L., 1977. Mechanically deboned goat, mutton and pork in frankfurters. J. Food Sci. 42: 193-196
Mechanically recovered meat gave the finished sausage a slightly darker colour.

In this work, mechanically recovered meat was added to homogeneous light-coloured sausage, in which organoleptic qualities were clearly apparent.

Acknowledgements. We are grateful to the foundation of Kyllikki and Uolevi Lehikoinen and the production plant of Lihapolar Oy for financial support during this study.

9 Froning, G.W., Arnold, R.G. and Mandigo, R.W., 1970. Quality and stability of frankfurters containing $15 \%$ mechanically deboned turkey meat. J. Food Sci. 36: 974-978

10 Joseph, A.L., Berry, B.W., Cross, H.R. and Maga, J.A., 1978. Utilization of mechanically deboned beef in cooked salami. J. Food Sci. 43: 307-311

11 Pонла, M.S., 1974. Methode zur Bestimmung der Hitzestabilităt von Wurstbrät, Fleischwirtsch., 54: 1984-1986

12 Riıhonen, L., Laine, J. and KÄrkKÄInen, T., 1990. Storage properties and quality of meats deboned by different methods. J.Agric. Sci. Finl. 62: 381-395

13 Puolanne, E. and Turkkı, P., 1985. The effect of freeze storage on the water binding capacity of the raw materials of cooked sausage. Proc. 31st Eur. Meet. Meat Res. Work.,Sofia, pp 583-586

14 Love, J.D., 1983. The role of heme iron in the oxidation of lipids in red meats. J.Food Sci. 37: 117-120

15 Field, R.A., 1976. Increased, Animal Protein Production with Mechanical Deboners, World Review of Animal Production, Vol. XII, No. 1 Jan-Mar. 61-73

16 Умıтн, D.M., 1987. Functional and biochemical changes in deboned turkey due to frozen storage and lipid oxidation. J.Food Sci. 52: 22-27

Deb Ms received July 121990 


\section{SELOSTUS}

\section{Mekaanisesti luista erotetun lihan käyttö makkaramassassa}

L. Riihonen, ${ }^{*}$ K. Hämäläinen** ja

E. Väänänen**

* Lihateollisuuden tutkimuskeskus PL 56, SF-13101 Hämeenlinna, Suomi

** Osuusteurastamo Karjaportti

PL 60, SF-50101 Mikkeli, Suomi

Työssä tutkittiin mekaanisesti luista erotetun lihan (MDM) käyttöă homogeenisessa makkaramassassa. Koemakkara sisälsi $7.50 \%$ mekaanisesti luista erotettua lihaa, joka oli erotettu joko paineeseen perustuvalla Inject Star koneella tai kaavintaan perustuvalla Poss koneella. Makkaramassan vesipitoisuutta muutettiin vălillä $28.36 \%-43.36 \%$.

Tuloksista voidaan havaita, ettă koemakkaroiden sisăltảessả saman mäărän eri koneilla erotettua lihaa mak- karoiden värit olivat hyvin samanlaiset. Kalsiumpitoisuus oli $0.11 \%-0.18 \%$ ja vastaavasti tuhkapitoisuus $2.6 \%$ $2.9 \%$. Kaikkien koemakkaroiden pH-luku oli sama 6.4. Makkarat, joissa käytettiin Inject Star koneelta saatua mekaanisesti luista erotettua lihaa sisälsivăt vähemmăn rasvaa kuin vastaavat Poss koneelta saatua lihaa sisăltävăt makkarat. Kemiallisen laadun perusteella säilyvyysaika koemakkaroilla, joissa oli eri koneilta peräisin olevaa lihaa, oli samanlainen. 